\title{
Seasonal Body Composition Variations in Adolescent Soccer Players
}

\author{
Variaciones Estacionales de Composición Corporal en Jugadores Adolescentes de Fútbol
}

Dejan M. Madic ${ }^{1}$; Slobodan Andrasic²; Marko Gusic ${ }^{1}$; Slavko Molnar ${ }^{1}$; Danilo Radanovic ${ }^{1}$ \& Nebojsa Trajkovic ${ }^{1}$

MADIC, D. M.; ANDRASIC, S.; GUSIC, M.; MOLNAR, S.; RADANOVIC, D. \& TRAJKOVIC, N. Seasonal body composition variations in adolescent soccer players. Int. J. Morphol., 36(3):877-880, 2018.

SUMMARY: The aim of this study was to examine seasonal variations in body composition in adolescent soccer players. A total of 64 young male soccer players (aged 14-18 years) were recruited for this research. Body composition was assessed using the Bioelectric impedance analysis. The variables were body mass, body fat, muscle mass, fat free mass, total body water, BMI, body fat $\%$, basic metabolic rate. Body mass did not change across the three measurement occasions. Body fat mass and body fat $\%$ significantly changed between test intervals $(\mathrm{p} \leq 0.05)$. There were no significant differences in other variables between measurements performed during the season. In conclusion, body fat has changed significantly from the start of the season to the end of the competitive period in adolescent soccer players, in accordance with earlier studies.

KEY WORDS: Football; Morphology; Differences; Athletes.

\section{INTRODUCTION}

A great number of scientific studies have focused on physiological demands of soccer by performing physiological measurements (Bangsbo et al., 2007). Using time - motion analysis, it has been demonstrated that elite players typically cover a total distance of $9-12 \mathrm{~km}$ during a game (Mohr et al., 2003). The maintenance of fitness during a season is a key target for every team (Koutedakis, 1995) but this is a complex process reflecting the diverse physical demands of the game.

Many factors are important for the success in soccer. However, the importance of body composition in soccer remains speculative. Over recent years, certain anthropometric and fitness characteristics were identified that significantly contribute towards success in soccer (Carling et al., 2009). The measurement of body composition in elite soccer players has received widespread attention especially with respect to playing positions and to the description of changes across the playing season (Cossio-Bolaños et al., 2012). Body composition in soccer players is likely to change during the course of the competitive season as a result of training and competition, habitual activity and diet (Ostojic, 2003).

Seasonal changes in body composition were previously studied among professional English (Thomas \& Reilly, 1979; Dunbar \& Power, 1997; Wallace et al., 2007; Clark et al.,
2008), Japanese (Hoshikawa et al., 2005), Spanish (Casajús, 2001) Singapore (Aziz et al., 2005) and Turkish (Kutlu et al., 2007) players. In elite soccer, previous research has shown that percent body fat and body mass values differ greatly between goalkeepers and the other outfield positions (Reilly, 2008). Caldwell \& Peters (2009) have investigated seasonal variations in fitness among semi-professional football players and found significant decline in the level of fitness from the end of the season to the beginning of the new one. Ostojic found that body fat content of elite professional soccer players significantly dropped during the conditioning and competitive period and increased during the off-season. In addition, Ostojic \& Zivanic (2001) pointed out the importance of body fat in soccer. The aforementioned authors stated that when body fat content decreases during the season, players became faster.

Although seasonal changes have been investigated in elite and professional male and female soccer players and in collegiate teams pre and postseason and in starters and nonstarters, there is a paucity of research involving adolescent players who experience considerable additional employment demands that may limit their capacity for more regular training and conditioning. The aim of this study, therefore, was to investigate the seasonal variations in body composition of adolescent soccer players over a 12-month period.

${ }^{1}$ Faculty of Sport and Physical Education, University of Novi Sad, Serbia.

${ }^{2}$ Faculty of Economics in Subotica, University of Novi Sad, Serbia. 


\section{MATERIAL AND METHOD}

Participants. A total of 64 young male soccer players (aged 14-18 years) were recruited (Table I). Written informed consent was obtained from the players and their parents. All participants were from a professional soccer club and completed on average $10 \mathrm{~h}$ of combined soccer training and competitive play per week. The experimental protocol received approval from the Institutional Ethics Committee from the Faculty of Sport and Physical Education, University of Novi Sad.

Measurements. Body height was measured under standard conditions. The InBody 230 (Biospace Co. Inc., Seoul, South Korea) Bioelectrical Impedance Analyzer (BIA) was used. This foot-to-foot, hand-to-hand and hand to-foot contact device uses two stainless-steel foot pad electrodes mounted on a platform scale and two stainless steel handles to allow for Tetrapolar 8point tactile electrode system. The platform scale uses a single load cell to measure body mass (which with a measure of stature) and calculate body mass index (BMI). Body fat percentage is determined using a summation of segmental lean analysis to determine total lean body mass, fat mass, and ultimately the proportion of fat to total weight mass fraction. The subjects entered the testing area and removed their shoes and socks and wore only light clothing. Positioned on the InBody 230, the age, sex, and stature were entered. The InBody 230 displays a visual cue (photo) how and when to hold the handles during the impedance measure. We registered the following body composition variables: fat-free mass, percentage of fat mass (BF\%), muscle mass, body fat mass, total body water (TBW), BMI and Basal metabolic rate (BMR).

\section{Training program during season}

Preseason Conditioning. Training during preseason consisted of 6 sessions per week. The session lasted approximately 120-150 minutes. Throughout the training conditioning sessions in weeks $1-2$ of the preseason, the training consisted of $50 \%$ aerobic conditioning (distance running) and $20 \%$ of high-intensity short sprint drills and agility-based drills; also $20 \%$ muscle strength training, legs and upper body weight training (free weights and machine weights) and functional training and $10 \%$ tactical training. Moreover, during all preseason training sessions, warm up exercises were performed regularly with stretching after a warmup and at the end of training sessions. The conditioning training sessions for preseason weeks 3-7 consisted of 15 $\%$ aerobic conditioning and $25 \%$ high-intensity shuttlerunning and $25 \%$ small sided games; also $10 \%$ basic muscle strength training and $25 \%$ tactical training. Moreover, 6 friendly games were also played.
Seasonal Conditioning. Players had their usual technical/ tactical sessions during the week. Seasonal conditioning took place twice a week, mostly on Tuesday and Thursday lasting 90-120 minutes each. Sessions 1-18 consisted of: $40 \%$ highintensity distance running small-sided games and $25 \%$ sprint and agility-based drills and $20 \%$ leg muscle strength training (plyometrics) and $15 \%$ tactical training/set plays; flexibility exercises were also performed (5-minute warmup/5-minute cool-down).

From week 18 to the end of the season, conditioning training was only performed on a Wednesday. In order to help keep the players fresh and prevent fatigue, the intensity and duration of conditioning training was reduced in the second half of the season. Aerobic and anaerobic training intensity in these sessions was reduced.

Statistical Analyses. Data were analyzed using the SPSS program (SPSS version 20.0, Chicago, IL). Mean \pm SD were calculated. A repeated-measures analysis of variance (ANOVA) was applied to examine if there were differences among the different time points in each dependent variable. When $\mathrm{F}$ ratios were significant, post hoc comparisons of means were performed with Bonferroni's multiple comparison tests. Statistical significance was accepted at $\mathrm{p} \leq 0.05$.

\section{RESULTS}

Body mass did not change across the three measurement occasions (Table II). Mean body mass ranged from $68.8 \mathrm{~kg} \pm 9.1$ (T1) and $69.7 \mathrm{~kg} \pm 7.9$ (T3). Body fat mass significantly changed between test intervals and ranged from a low of 6.51 (T3) and a high of 7.70 (T2) (Table II).

Body fat percent at time 3 was significantly lower compared with time $2(\mathrm{p} \leq 0.05)$. Time 2 was higher than time 1 , however without statistical significance $(\mathrm{p} \geq 0.05)$; There were no significant differences in other measurements performed during the season.

Table I. Basic descriptive statistics of adolescent soccer players.

$\begin{array}{ll}\text { Age } & 15.8 \pm 0.8 \\ \text { Height } & 178.54 \pm 6.2 \\ \mathrm{VO}_{2 \max } & 52.1 \pm 2.04 \\ \text { Experience (years) } & 6.3 \pm 2.6 \\ \text { Training (min_week-1) } & 405 \pm 126\end{array}$


Table II. Body composition during season in adolescent soccer players.

\begin{tabular}{lccc}
\hline & $\mathrm{T} 1$ & $\mathrm{~T} 2$ & $\mathrm{~T} 3$ \\
& Mean $\pm \mathrm{SD}$ & Mean $\pm \mathrm{SD}$ & Mean $\pm \mathrm{SD}$ \\
\hline Body mass & $68.81 \pm 9.1$ & $69.56 \pm 8.9$ & $69.77 \pm 7.9$ \\
Body fat mass & $7.42 \pm 3.43$ & $7.70 \pm 2.87$ & $6.51 \pm 2.23^{*}$ \\
Muscle mass & $34.88 \pm 4.60$ & $35.196 \pm 4.956$ & $36.11 \pm 4.85$ \\
TBW & $44.93 \pm 5.507$ & $45.27 \pm 5.866$ & $46.25 \pm 5.75$ \\
Fat free mass & $61.38 \pm 7.576$ & $61.86 \pm 8.096$ & $63.26 \pm 7.89$ \\
BMI & $21.38 \pm 2.23$ & $21.70 \pm 2.025$ & $21.61 \pm 1.66$ \\
BF \% & $10.64 \pm 3.74$ & $11.04 \pm 3.43$ & $9.42 \pm 3.19^{*}$ \\
BMR & $1695.86 \pm 163.58$ & $1770.2712 \pm 248.54$ & $1736.24 \pm 170.53$ \\
\hline
\end{tabular}

*- significantly different from T2; T1 - first measurement; $\mathrm{T} 2$ - second measurement; $\mathrm{T} 3$ - third measurement; $\mathrm{BF} \%$ - percentage of fat mass, TBW - total body water, BMR - Basal metabolic rate

\section{DISCUSSION}

The purpose of this study was to investigate seasonal variations in body composition of adolescent soccer players over a 12-month period. The main finding of the present study was that body fat content of elite professional soccer players significantly dropped during the competitive period and increased during the transition period. The values obtained for body composition are similar to those previously reported. Previous estimates of fat values have ranged between $7.9 \%$ and $19.3 \%$ (White et al., 2011), while $\sim 11 \%$ seems broadly normal for elite players (Rico-Sanz, 1998; Rienzi et al., 2000; Ostojic).

Burke et al. (1986) and Reilly suggested that football players can accumulate body fat in the off-season and lose weight more during pre-season training time than in other periods. However, despite the fact that preseason conditioning phase is the most intensive, soccer players in our study lost more fat during the competitive phase than conditioning period, reaching lowest levels at the end of the season. It could be speculated that the reason was intensive training and competition schedules, dietary habits and psychological effects. Our results are in line with Ostojic who stated that body fat of professional soccer players significantly drop during competitive periods. Another possible reason why body fat percent continued to decrease toward the end of the season is the change in the way of conditioning. Small-sided games and high intensity training have replaced the traditional continuous running during season, which could have influenced the body weight status of players towards the end of the season. Moreover, the second measurement was after the transition period which appears to represent a period of significant reduction in fitness so the results for body fat $\%$ were somewhat higher.
Morphological characteristics are important for high level performance in soccer (Reilly et al., 2000). Body mass did not change significantly among the 3 measurements. On the other hand, body fat was reduced significantly after the transition period and remained relatively constant throughout the competitive period. This could be due to the fact that lean body mass was increased, because soccer players were involved in strength training programs during competition period. This is in line with Casajús and recently Kalapotharakos et al. (2011). Lean body mass and muscle mass were higher towards the end of season compared to the beginning which could be due to a conditioning program that is composed of total conditioning, with the continuous development of aerobic capacity, power and speed, designed to maintain and improve fitness with associated benefits in body composition. However, some studies did not find seasonal variations in body composition Clark et al. and Aziz et al., from several measurements in professional English Premier League and Singapore players. Clark et al. stated this this may be due to the poor reliability of data collection method (Bioelectric impedance analysis) while Aziz et al. suggested that players in their study had low level of preseason body fat $(\sim 11 \%)$ which could be a possible reason.

The limitations of this study is the absence of recording training load during the season period. Moreover, we performed only 3 measurements. Four or more measurements could give more objective picture of body composition status among adolescent soccer players. Nevertheless, this type of testing can track fitness and can help to identify changes in body composition parameter throughout the season. 
In conclusion, body fat has changed significantly from the start of the season to the end of the competitive period in adolescent soccer players, in accordance with earlier studies. These body composition parameters should be taken into consideration by the coaches for planning of the training program to maximize the performance of adolescent soccer players and to minimize the risk of injuries.

MADIC, D. M.; ANDRASIC, S.; GUSIC, M.; MOLNAR, S.; RADANOVIC, D. \& TRAJKOVIC, N. Variaciones estacionales de composición corporal en jugadores adolescentes de fútbol. Int. J. Morphol., 36(3):877-880, 2017.

RESUMEN: El objetivo de este estudio fue examinar las variaciones estacionales en la composición corporal en jugadores adolescentes de fútbol. Un total de 64 jóvenes jugadores de fútbol masculino (14-18 años de edad) fueron reclutados para esta investigación. La composición corporal se evaluó mediante el uso del análisis de impedancia bioeléctrica. Las variables fueron masa corporal, grasa corporal, masa muscular, masa libre de grasa, agua corporal total, IMC, porcentaje de grasa corporal, tasa metabólica básica. La masa corporal no cambió en las tres ocasiones de medición. La masa de grasa corporal y el porcentaje de grasa corporal cambiaron significativamente entre los intervalos de prueba $(\mathrm{p} \leq 0.05)$. No hubo diferencias significativas en otras variables entre las mediciones realizadas durante la temporada. En conclusión y de acuerdo a estudios anteriores, la grasa corporal cambió significativamente desde el inicio de la temporada hasta el final del período competitivo en jugadores adolescentes de fútbol.

PALABRAS CLAVE: Fútbol; Morfología; Diferencias; Atletas.

\section{REFERENCES}

Aziz, A. R.; Tan, F. Y. H. \& Teh, K. C. Variation in Selected Fitness Attributes of Professional Soccer Players during a League Season. In: Reilly, T.; Cabri, J. \& Araújo, D. (Eds.). Science and Football. London, Routledge, 2005. pp.134-8.

Bangsbo, J.; Iaia, F. M. \& Krustrup, P. Metabolic response and fatigue in soccer. Int. J. Sports Physiol. Perform., 2(2):111-27, 2007.

Burke, L. M.; Gollan, R. A. \& Read, R. S. Seasonal changes in body composition in Australian Rules footballers. Br. J. Sports Med., 20(2):69-71, 1986.

Caldwell, B. P. \& Peters, D. M. Seasonal variation in physiological fitness of a semiprofessional soccer team. J. Strength Cond. Res., 23(5):1370-7, 2009.

Carling, C.; le Gall, F.; Reilly, T. \& Williams, A. M. Do anthropometric and fitness characteristics vary according to birth date distribution in elite youth academy soccer players? Scand. J. Med. Sci. Sports, 19(1):3-9, 2009.

Casajús, J. A. Seasonal variation in fitness variables in professional soccer players. J. Sports Med. Phys. Fitness, 41(4):463-9, 2001.

Clark, N. A.; Edwards, A. M.; Morton, R. H. \& Butterly, R. J. Season-to-season variations of physiological fitness within a squad of professional male soccer players. J. Sports Sci. Med., 7(1):157-65, 2008.

Cossio-Bolaños, M.; Portella, D. L.; Hespanhol, J. E.; Fraser, N. \& de Arruda, M. Body size and composition of the elite Peruvian soccer player. J. Exerc. Physiol. Online, 15(3):30-8, 2012.

Dunbar, G. \& Power, K. Fitness Profiles of English Professional and Semi Professional Soccer Players Using a Battery of Field Tests. In: Reilly, T.;
Bangsbo, J. \& Hughes, M. (Eds.). Science and Football. London, E. \& F. N. Spon, 1997. pp.27-31.

Hoshikawa, Y.; Kanno, A.; Ikoma, T.; Muramatsu, M.; Iida, T.; Uchiyama, A. \& Nakajima, Y. Off-Season and Pre-Season Changes in Total and Regional Body Composition in Japanese Professional Soccer League Players. In: Reilly, V.; Cabri, J. \& Araújo, D. (Eds.). Science and Football. London, Routledge, pp.160-5, 2005.

Kalapotharakos, V. I.; Ziogas, G. \& Tokmakidis, S. P. Seasonal aerobic performance variations in elite soccer players. J. Strength Cond. Res., 25(6):15027,2011.

Koutedakis, Y. Seasonal variation in fitness parameters in competitive athletes. Sports Med., 19(6):373-92, 1995.

Kutlu, M.; Sofi, N. \& Bozkus, T. Changes in body compositions of elite level amateur and professional soccer players during the competitive season. Spor Hekim. Derg., 42 Suppl.:21-5, 2007.

Mohr, M.; Krustrup, P. \& Bangsbo, J. Match performance of high-standard soccer players with special reference to development of fatigue. J. Sports Sci., 21(7):519-28, 2003.

Ostojic, S. M. \& Zivanic S. Effects of training on anthropometric and physiological characteristics of elite Serbian soccer players. Acta. Biol. Med. Exp., 27:76, 2001.

Ostojic, S. M. Seasonal alterations in body composition and sprint performance of elite soccer players. J. Exerc. Phys., 6(3):11-4, 2003.

Reilly, T. The Science of Training - Soccer. London, Routledge, 2008.

Reilly, T.; Bangsbo, J. \& Franks, A. Anthropometric and physiological predispositions for elite soccer. J. Sports Sci., 18(9):669-83, 2000.

Rico-Sanz, J. Body composition and nutritional assessments in soccer. Int. J. Sport Nutr., 8(2):113-23, 1998.

Rienzi, E.; Drust, B.; Reilly, T.; Carter, J. E. \& Martin, A. Investigation of anthropometric and work-rate profiles of elite South American international soccer players. J. Sports Med. Phys. Fitness, 40(2):162-9, 2000.

Thomas, V. \& Reilly, T. Fitness assessment of English league soccer players through the competitive season. Br. J. Sports Med., 13(3):103-9, 1979.

Wallace, J.; Billows, D.; George, K. \& Reilly, T. Bone mineral density and body composition changes during a Premier League association football season. J. Sports Sci. Med., Suppl. 10:53-4, 2007.

White, J. E.; Emery, T. M.; Kane, J. E.; Groves, R. \& Risman, A. B. Pre-Season Fitness Profiles of Professional Soccer Players. In: Reilly, T.; Lees, A.; Davids, K. \& Murphy, W. J. (Eds.). Science and Football (Routledge Revivals). Proceedings of the first World Congress of Science and Football, Liverpool, 13-17th April 1987. London, Taylor \& Francis Group, 2011. pp.164-71.

Corresponding author:

Slobodan Andrasic

Faculty of Economics in Subotica

University of Novi Sad

9-11 Segedin road

Subotica

SERBIA

Email: andrasic@ef.uns.ac.rs

Received: 23-12-2017

Accepted: 21-03-2018 